浅 W 谷

\title{
Shallow valley and dent
}

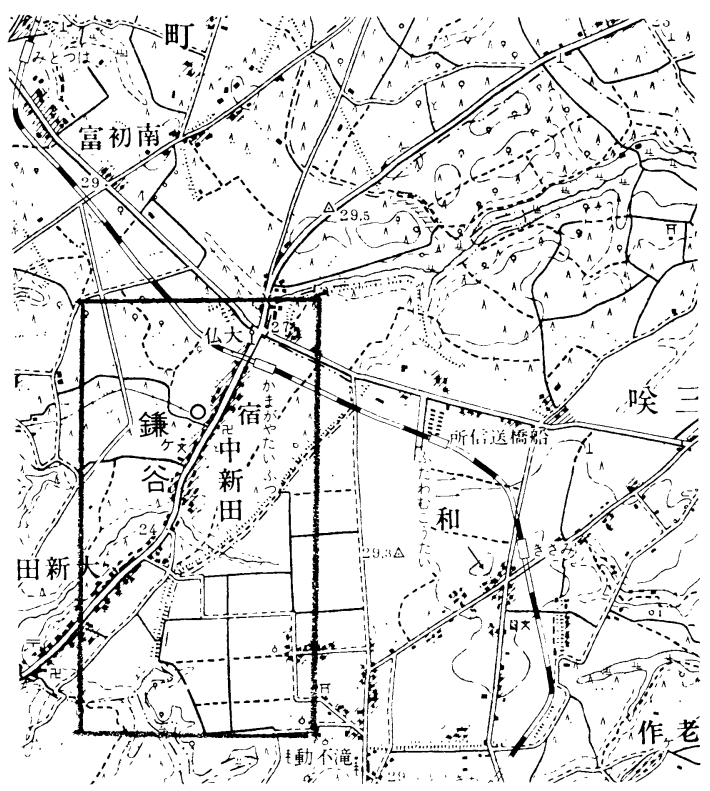

この地域は千葉県北部にひろがる下総台地の一部である。下総台地はお拉むね $25 \mathrm{~m} 〜 40 \mathrm{~m}$ 高度 を持ち北に向かって傾斜している。台地を構成する地質は成田層（砂層）で，その上部にローム層 (3. $5 \mathrm{~m})$ がのっている下末吉面に対比される海成の段丘である。台地面は谷壁が急傾斜な谷によっ て侵蝕され，その上流部には浅い谷が発達している。浅い谷は周囲の表面より $0.5 \mathrm{~m}$ 数 $\mathrm{m}$ 程低く 豪雨時には集水区域となるので冠水しやすい。また表流水の通路となるので一時的に侵蝕，堆積に よる災害をもたらす。そのため最近都市化がすすんでる台地上の浅い谷は盛土が行なわれ渠溝など の排水施設が完備され，防災対策が施されている。

(鈴木 美和子)

It is well developed that shallow valley and dent over the surface of the Shimofusa Daich (terrace) following the upper side of valley plain which has incised this terrace.

As the level of these areas is lower about $0.5 \sim 3$ meters than the terrace's surface, they have been blooded zone on this terrace on the occasion of heavy rains. Under these circumstances, owing to gathered spill-over water on the surface of this terrace, it is of frequent that the processes of erosion and/or deposition in these areas. 


$$
\text { 河 原 }
$$

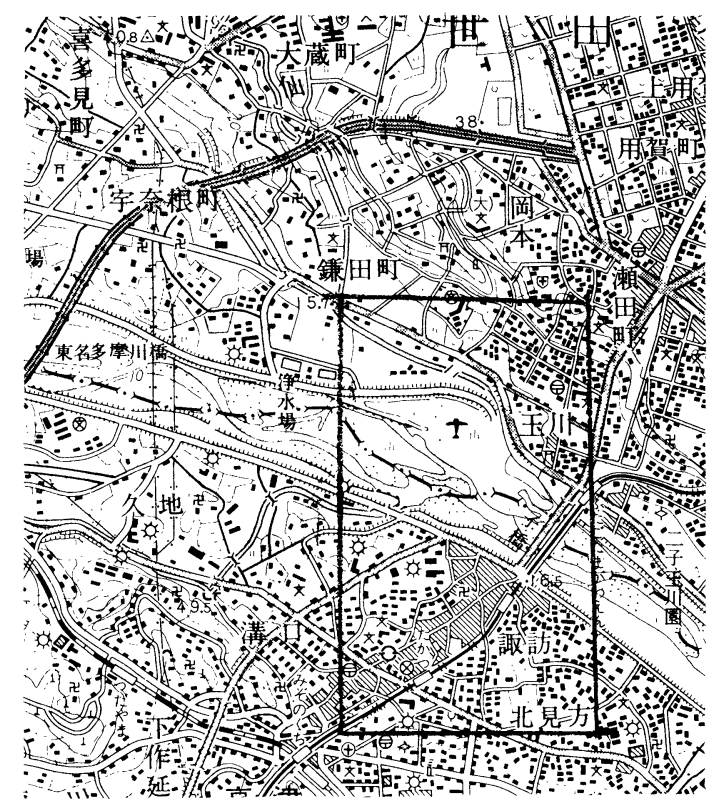

多摩川の下流部砧付近の河原である。異常高水，洪水時に冠水する土地である高水敷 $(\mathrm{H})$ は水田 畑地, あるいは運動場, ゴルフ場などのようなレクレーション施設に利用されている。るた平水, 豊水時に冠水する土地である低水敷 ( L ) は冠水の頻度が高いため裸地となっている場合が多い。川 の両岸の堤防にかこまれた部分を堤外地といい，それ以外の土地を堤内地と呼ぶ。堤外地内に建て られた家屋は堤外家屋といっている。

（鈴木 美和子）

Regarding to the river bed between both banks of the river in this topographical map. The high water river bed which is scarcely possible to suffer bloods has been used for paddy fields, playgrounds and golf grounds.

The low water river bed in this area has, however, let be as nacked place or rough bush for they are frequently covered with water. 